\section{OP0210 EFFICACY AND SAFETY OF SM03, A RECOMBINANT ANTI-HUMAN CD22 MONOCLONAL ANTIBODY IN CHINESE PATIENTS WITH RHEUMATOID ARTHRITIS A PHASE II RANDOMIZED, DOUBLE-BLIND, MULTI- DOSE, PLACEBO-CONTROLLED STUDY}

J. Li', M. Li ${ }^{1}$, D. Wu' ${ }^{2}$, J. Zhou ${ }^{1}$, S. O. Leung ${ }^{3}$, F. Zhang ${ }^{1} .{ }^{1}$ Peking Union Medical College Hospital, Chinese Academy of Medical Sciences \& Peking Union Medical College, Beijing, China; ${ }^{2}$ Peking Union Medical College Hospital, Chinese Academy of Medical Sciences \& Peking Union Medical College, Beijing, China; ${ }^{3}$ SinoMab BioScience, Ltd, Shenzhen, China

Background: Rheumatoid arthritis (RA) is a common chronic inflammatory rheumatic disease in China. SM03 is a novel chimeric monoclonal antibody $(\mathrm{mAb})$ specific to the $B$ cell restricted antigen $\mathrm{CD} 22$ developed for the treatment of rheumatoid arthritis (RA) and other $B$ cell related immunological diseases. Objectives: We aim to evaluate the efficacy and safety of $\mathrm{SM} 03$ in patients with moderately-to-severely active RA in China.

Methods: In this 24-week Phase II randomized, double-blind, multi-dose, placebo-controlled study, 156 patients were randomized with ratio of 1:1:1 to receive $3600 \mathrm{mg}$ cumulative dose of SM03 (group A, 600 mg * 6 infusions at 0, 2, 4, 12, 14 , and 16 week), $2400 \mathrm{mg}$ cumulative dose of SM03 (group B, $600 \mathrm{mg}^{*} 4$ infusions at $0,2,12$, and 14 week) and placebo (group C). All patients remained on background treatment of MTX. Efficacy and safety were assessed at weeks 4, 8 , 12,16 and 24. The primary efficacy end point was the American College of Rheumatology $20 \%$ improvement criteria (ACR20) response rate at week 24 .Safety profile was also assessed.

Results: ACR20 response rates at 24-week were significant for group A $65.3 \%$, $\mathrm{p}=0.002)$ and $\mathrm{B}(56.9 \%, \mathrm{p}=0.024)$ versus group $\mathrm{C}(34.0 \%)$. There is no significant difference in ACR20 between group $A$ and $B$ (Table 1 \& Fig 1). We did not observe significant difference in any adverse event ( $A E)$ among group A $(35.3 \%), B(51.9 \%)$ and C (34.6\%)(Table 2). In groups A and B, $13(12.6 \%)$ patients reported treatment-related infection, and $5(6.8 \%)$ patients were positive in anti-drug antibodies analysis. In group A (higher dose), 3.9\% patient had AE of treatment-related infections. No patients reported treatment-related severe infection or any malignancies caused by treatment in groups A and B.

Table 1. Summary of ACR/DAS EULAR Responses of Patients with RA to SM03 at Week 24

\begin{tabular}{|c|c|c|c|}
\hline Response & $\begin{array}{c}\text { Group C } \\
\text { Placebo+MTX } \\
(n=47)\end{array}$ & $\begin{array}{c}\text { Group A SM03 } \\
600 \mathrm{mg}^{*} 6+\mathrm{MTX} \\
(\mathrm{n}=49)\end{array}$ & $\begin{array}{c}\text { Group B SM03 } \\
600 \mathrm{mg}^{*} 4+\mathrm{MTX} \\
(\mathrm{n}=51)\end{array}$ \\
\hline ACR 20 & $34.0 \%$ & $65.3 \%$ * & $56.9 \%$ * \\
\hline ACR 50 & $17.0 \%$ & $44.9 \%$ ** & $29.4 \%$ \\
\hline ACR 70 & $4.3 \%$ & $18.4 \%^{\star \star *}$ & $9.8 \%$ \\
\hline EULAR response good \& moderate & $40.4 \%$ & $75.5 \% \wedge$ & $70.6 \% \wedge$ \\
\hline EULAR response good & $12.8 \%$ & $30.6 \% \mathrm{M}$ & $15.7 \%$ \\
\hline Change of DAS28 from baseline & -0.70 & $-1.65^{M M}$ & $-1.38 \mathrm{Mn}$ \\
\hline DAS $28 \leq 3.2$ & $14.9 \%$ & $30.6 \%$ & $19.6 \%$ \\
\hline DAS $28<2.6$ & $8.5 \%$ & $18.4 \%$ & $5.9 \%$ \\
\hline
\end{tabular}

Compared with group $\mathrm{C}$ (Placebo), results of group $\mathrm{A}$ and $\mathrm{B}$ were shown respectively

${ }^{\star} \mathrm{P}=0.002, \mathrm{P}=0.024 ;{ }^{\star \star} \mathrm{P}=0.003 ;{ }^{\star \star \star} \mathrm{P}=0.03$;

$\wedge \mathrm{P}<0.001, \mathrm{P}=0.003 ; \sim \mathrm{P}=0.034 ; \sim \mathrm{P}=0.008, \mathrm{P}=0.047$

Table 2. Profile of Adverse Events

\begin{tabular}{|c|c|c|c|}
\hline Adverse event, N (\%) & Group $\mathrm{C}(\mathrm{N}=52)$ & Group $\mathrm{A}(\mathrm{N}=51)$ & Group $\mathrm{B}(\mathrm{N}=52)$ \\
\hline Any $A E$ & $18(34.6)$ & $18(35.3)$ & $27(51.9)$ \\
\hline$A E$-drug related & $7(13.5)$ & $5(9.8)$ & $8(15.4)$ \\
\hline AE-mild & $16(30.8)$ & $15(29.4)$ & $24(46.2)$ \\
\hline AE-moderate & $2(3.8)$ & $2(3.9)$ & $3(5.8)$ \\
\hline AE-severe & - & $1(2.0)$ & - \\
\hline AE-leading to discontinuation & - & $2(3.9)$ & - \\
\hline Serious adverse event, SAE & $1(1.9)$ & $1(2.0)$ & - \\
\hline $\mathrm{AE}-1^{\text {st }}$ cycle (week 0-12) & 15 & 13 & 22 \\
\hline$A E-2^{\text {nd }}$ cycle (week 12-24) & 9 & 9 & 14 \\
\hline
\end{tabular}

Conclusion: In Chinese patients with active RA, both $2400 \mathrm{mg}$ and $3600 \mathrm{mg}$ cumulative doseof $\mathrm{SM03}$, in combination with MTX were efficacious and well tolerated. throughout the 24 weeks of treatment.Moreover, SM03 has demonstrated a good safety profile, especially in terms of treatment-related infection, malignancy and immunogenicity.

References: None

Disclosure of Interests: None declared

DOI: 10.1136/annrheumdis-2020-eular.1383

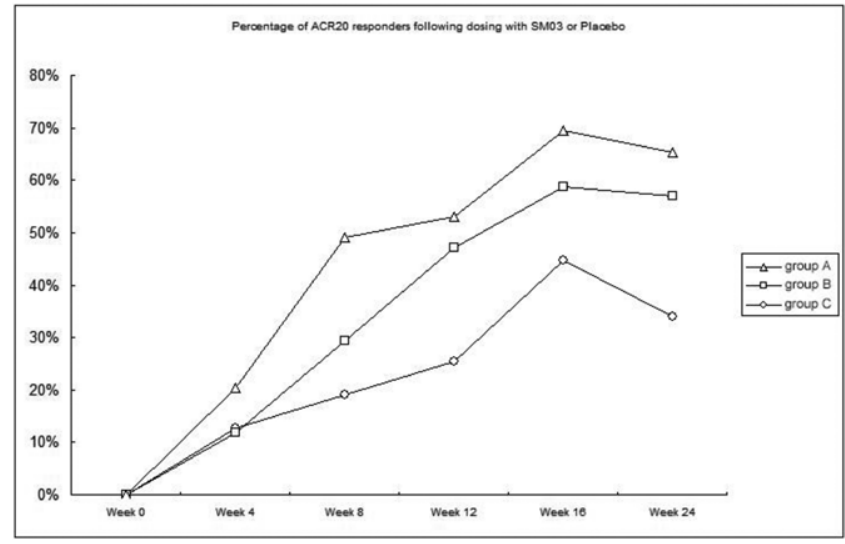

Fig 1. Percent of Patients Achieving ACR 20 Response by Visit

\section{OP0211 \\ TIME TO DISCONTINUATION OF TOFACITINIB AND TNF INHIBITORS IN RHEUMATOID ARTHRITIS PATIENTS WITH AND WITHOUT METHOTREXATE: DATA FROM A RHEUMATOID ARTHRITIS COHORT}

M. Movahedi ${ }^{1,2}$, A. Cesta ${ }^{1}$, X. LI $^{1}$, E. Keystone ${ }^{3}$, C. Bombardier ${ }^{1,3,4}$ on behalf of the OBRI Investigators. ${ }^{1}$ Toronto General Hospital Research Institute, University Health Network, Ontario Best Practices Research Initiative, Toronto, Canada; ${ }^{2}$ Institute of Health Policy, Management and Evaluation, University of Toronto, Toronto, Canada; ${ }^{3}$ Division of Rheumatology, Mount Sinai Hospital, Toronto, Canada; ${ }^{4}$ Department of Medicine (DMO) and Institute of Health Policy, Management, and Evaluation (IHPME), Toronto, Canada

Background: Tofacitinib (TOFA) is an oral, small molecule drug used for rheumatoid arthritis (RA) treatment and is prescribed alone or with methotrexate (MTX). Tofa can be used as an alternative to biologic disease modifying antirheumatic drugs (bDMARDs) including tumor necrosis factor inhibitors (TNFi). Objectives: We aimed to evaluate the discontinuation rate of this drug, with and without concurrent MTX in comparison with TNFi, in patients with RA in the Ontario Best Practices Research Initiative (OBRI).

Methods: RA patients enrolled in the OBRI initiating their TOFA or TNFi (adalimumab, certolizumab, etancercept, golimumab, and infliximab) within 30 days prior to or any time after enrolment between $1^{\text {st }}$ June 2014 (TOFA approval date in Canada) and $31^{\text {st }}$ Dec 2018 were included. Time to discontinuation (due to any reason) were assessed using Kaplan-Meier survival (adjusted for propensity score using inverse probability of treatment weight) to compare patients with and without MTX use at initiation of TOFA or TNFi.

Results: A total of 565 patients initiated TOFA $(n=208)$ or TNFi $(n=357)$. Of those, $106(51 \%)$ and $222(62 \%)$ were treated with MTX in the TOFA and TNFi group, respectively and mean (SD) disease duration were 13.1 (9.4) and 9.5 (9.4) years. In the TOFA group, $86 \%$ were female and mean (SD) age at treatment initation was 60.4 (10.6) years. In the TNFi group $82 \%$ were female and mean age (SD) at treatment initation was 57.0 (12.6) years. The TOFA group was more likely to have prior biologic use $(61.5 \%)$ compared with the TNFi group (31\%) At treatment initiation, the mean (SD) clinical disease activcity index was 24.8 (12.1) in the TOFA group and 21.8 (12.0) in the TNFi group.

Over a mean of 17.3 month follow-up, discontinuation was reported in 75 (36\%) and $103(29 \%)$ of all TOFA and TNFi patients, respectively. After adjusting for propensity score, patients treated with TNFi and MTX remained on treatment longer than those treated without MTX (Logrank $p=0.002)$ while there was no significant difference in TOFA discontinuation in patients with and without MTX (Logrank $p=0.31$ ).

Conclusion: In this real world data study, we found that TOFA retention is similar in patients with and without MTX, while patients treated with TNFi and MTX remained on treatment longer than those treated without MTX. Merging data with other RA registries in Canada is proposed to increase study power and to provide more robust results.

Disclosure of Interests: Mohammad Movahedi Consultant of: Allergan, Angela Cesta: None declared, Xiuying Li: None declared, Edward Keystone Grant/ research support from: AbbVie; Amgen; Gilead Sciences, Inc; Lilly Pharmaceuticals; Merck; Pfizer Pharmaceuticals; PuraPharm; Sanofi, Consultant of: AbbVie; Amgen; AstraZeneca Pharma; Bristol-Myers Squibb Company; Celltrion; F. Hoffman-La Roche Ltd.; Genentech, Inc; Gilead Sciences, Inc.; Janssen, Inc; Lilly Pharmaceuticals; Merck; Myriad Autoimmune; Pfizer Pharmaceuticals, Sandoz, Sanofi-Genzyme, Samsung Bioepsis., Speakers bureau: AbbVie; Amgen; Bristol-Myers Squibb; Celltrion; F. Hoffman-La Roche Ltd, Janssen, Inc; Merck; Pfizer 
Pharmaceuticals; Sanofi-Genzyme; UCB, Claire Bombardier Grant/research support from: Dr Bombardier reports sources of funding for Ontario Best Practice Research Initiative Research grants from Abbvie, Janssen, Amgen, Medexus, Merck, Pfizer, and Novartis outside of the submitted work. Consulting Agreements: Abbvie, Covance, Janssen, Merck, Pfizer, Sanofi and Novartis outside of the submitted work. Advisory Board Membership: Hospira, Sandoz, Merck, Pfizer and Novartis outside of the submitted work.

DOI: 10.1136/annrheumdis-2020-eular.1745

\section{OP0212 ASSOCIATED WITH RHEUMATOID ARTHRITIS. NATIONAL MULTICENTER STUDY OF 263 PATIENTS}

C. Fernández-Díaz ${ }^{1}$, S. Castañeda ${ }^{2}$, R. Melero ${ }^{2}$, J. Loricera ${ }^{1}$, F. OrtizSanjuán $^{2}$, A. Juan-Mas ${ }^{2}$, C. Carrasco-Cubero ${ }^{2}$, S. Rodriguéz-Muguruza ${ }^{2}$, S. Rodrigez-Garcia ${ }^{2}$, R. Castellanos-Moreira ${ }^{2}$, R. Almodovar ${ }^{2}$, C. Aguilera $\mathrm{Cros}^{2}$, I. Villa-Blanco ${ }^{2}$, S. Ordoñez ${ }^{2}$, S. Romero-Yuste ${ }^{2}$, C. Ojeda-Garcia ${ }^{2}$, M. Moreno ${ }^{2}$, G. Bonilla ${ }^{2}$, I. Hernández-Rodriguez ${ }^{2}$, M. Lopez Corbeto ${ }^{2}$, J. L. Andréu Sánchez ${ }^{2}$, T. Pérez Sandoval ${ }^{2}$, A. López Robles ${ }^{2}$, P. Carreira ${ }^{2}$, N. Mena-Vázquez ${ }^{2}$, C. Peralta-Ginés ${ }^{2}, A$. Urruticoechea-Arana ${ }^{2}$, L. M. Arboleya Rodríguez ${ }^{2}$, J. Narváez², D. Palma Sanchez², O. Maiz-Alonso², J. Fernández-Leroy ${ }^{2}$, I. Cabezas-Rodriguez ${ }^{2}$, I. Castellví ${ }^{2}$, A. RuibalEscribano $^{2}$, J. De Dios-Jiménez Aberásturi ${ }^{2}$, P. Vela-Casasempere ${ }^{2}$, C. González-Montagut Gómez ${ }^{2}$, J. M. Blanco ${ }^{2}$, N. Alvarez-Rivas ${ }^{2}$, N. Del$\mathrm{Val}^{2}, \mathrm{M}$. Rodíguez-Gómez ${ }^{2}$, E. Salgado-Pérez ${ }^{2}$, C. Fernández-López ${ }^{2}$, E. C. Cervantes Pérez ${ }^{2}$, A. Devicente-Delmas ${ }^{2}$, B. Garcia-Magallon ${ }^{2}$, C. Hidalgo ${ }^{2}$, S. Fernández² ${ }^{2}$ E. García-Fernández², R. López-Sánchez², S. Castro ${ }^{2}$, P. Morales-Garrido ${ }^{2}$, A. García-Valle ${ }^{2}$, R. Expósito ${ }^{2}$, L. ExpositoPerez $^{2}$, L. Pérez Albaladejo ${ }^{2}$, Á. García-Aparicio ${ }^{2}$, M. A. González-Gay ${ }^{1}$, R. Blanco ${ }^{1} .{ }^{1}$ H. Marqués de Valdecilla, Santander, Spain; ${ }^{2}$ National Health System, Spain

Background: Interstitial Lung Disease (ILD) is a severe complication of Rheumatoid Arthritis (RA). Several conventional disease-modifying anti-rheumatic drugs (cDMARDs) and biologic (b) DMARDs may induce or impaired ILD-RA. Abatacept (ABA) may be useful in ILD-RA (1).

Objectives: To assess the efficacy and safety of ABA in a large series of ILD-RA for a long-term follow-up.

Methods: Multicenter open-level study of ILD-RA treated with at least 1 dose of ABA. ILD was diagnosed by high-resolution computed tomography (HRTC). We study these outcomes: a) 1-point change Modied Medical Research Council (MMRC); b) forced vital capacity (FVC) and/or DLCO improvement or decline $\geq 10 \%$; c) change in HRCT, d) change in DAS28. e) Prednisone dose. Values were collected at $0,3,6,12$ and then every 12 months.

Results: We studied 263 patients (150 women/113 men) (mean age;64.6 610 years), with ILD-RA. At ABA-onset they were smokers or exsmoker (53.8\%), positive APCC (88.6\%), median [IQR] duration of ILD of 12 [3-41.25] months, mean DLCO $(65.7 \pm 18.3)$ and FVC $(85.9 \pm 21.8)$

The ILD-pattern were usual interstitial pneumonia (UIP) (40.3\%), non-specific interstitial pneumonia (NSIP) $(31.9 \%)$ and others $(27.8 \%)$.

ABA was prescribed at standard subcutaneous $(125 \mathrm{mg} / \mathrm{w})$ in $196(74.5 \%)$ or intravenously $(10 \mathrm{mg} / \mathrm{kg} / 4 \mathrm{w})$ in $67(25.5 \%)$; in monotherapy $(n=111)$ or combined with cDMARDs $(n=152)$; especially leflunomide $(n=55)$, MTX $(n=46)$, or antimarials $(n=21)$.

After a mean follow-up of $22.7 \pm 19.7$ months most outcomes remain stable (Figure). Moreover, DAS28 improved from $4.5 \pm 1.5$ to $3.1 \pm 1.3$; prednisone dose reduced from a median 7.5 [5-10] to $5 \mathrm{mg}$ [5-7.5] and retention rate was $76.4 \%$. The main adverse effects were serious infections $(n=28)$, neoplasia $(n=3)$, serious infusion reaction $(n=1)$ and myocardial infarction $(n=1)$.

Conclusion: ABA seems effective and relatively safe in ILD-RA.

References:

[1] Fernández-Díaz C et al. Semin Arthritis Rheum. 2018; 48:22-27

Disclosure of Interests: Carlos Fernández-Díaz Speakers bureau: Brystol Meyers Squibb, Santos Castañeda: None declared, Rafael Melero: None declared, J. Loricera: None declared, Francisco Ortiz-Sanjuán: None declared, A. Juan-Mas: None declared, Carmen Carrasco-Cubero Speakers bureau: Janssen, MSD, AbbVie, Novartis, Bristol Myers Squibb, and Celgene, S, Rodriguéz-Muguruza: None declared, S. Rodrigez -Garcia: None declared, R. Castellanos-Moreira: None declared, RAQUEL ALMODOVAR Speakers bureau: Abbvie, Celgene, Janssen, Lilly, Novartis, Pfizer.

CLARA AGUILERA CROS: None declared, Ignacio Villa-Blanco Consultant of: UCB, Speakers bureau: Novartis, MSD, Lilly, Sergi Ordoñez: None declared, Susana Romero-Yuste: None declared, C. Ojeda-Garcia: None declared, Manuel Moreno: None declared, Gemma Bonilla: None declared, I. Hernández-Rodriguez: None declared, Mireia Lopez Corbeto: None declared, José Luis Andréu Sánchez: None declared, Trinidad Pérez Sandoval: None declared, Alejandra López Robles: None declared, Patricia Carreira Grant/research support from: Actelion, Roche, MSD, Consultant of: GlaxoSmithKline, VivaCell Biotechnology, Emerald Health Pharmaceuticals,

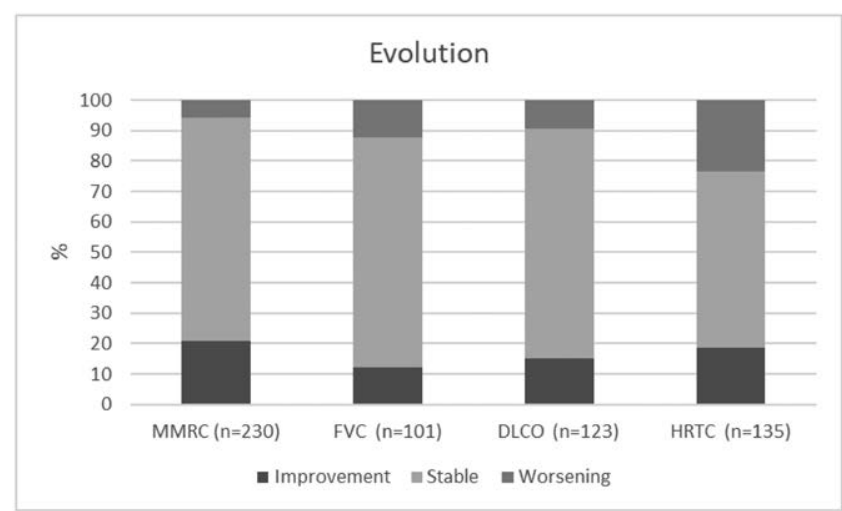

Boehringer Ingelheim, Roche, Speakers bureau: Actelion, GlaxoSmithKline, Roche, Natalia Mena-Vázquez: None declared, C. Peralta-Ginés: None declared, ANA URRUTICOECHEA-ARANA: None declared, Luis Marcelino Arboleya Rodríguez: None declared, J. Narváez: None declared, DESEADA PALMA SANCHEZ: None declared, Olga Maiz-Alonso: None declared, J. Fernández-Leroy: None declared, I. Cabezas-Rodriguez: None declared, Ivan Castellví Consultant of: Boehringer Ingelheim, Actelion, Kern Pharma, Speakers bureau: Boehringer Ingelheim, Actelion, Bristol-Myers Squibb, Roche, A. Ruibal-Escribano: None declared, JR De DiosJiménez Aberásturi: None declared, Paloma Vela-Casasempere: None declared, C. González-Montagut Gómez: None declared, J M Blanco: None declared, Noelia Alvarez-Rivas: None declared, N. Del-Val: None declared, M. Rodíguez-Gómez: None declared, Eva Salgado-Pérez: None declared, Carlos Fernández-López: None declared, E.C. Cervantes Pérez: None declared, A. Devicente-DelMas: None declared, Blanca Garcia-Magallon Consultant of: MSD, Speakers bureau: Pfizer, Amgen, Celgene, MSD, Cristina Hidalgo: None declared, Sabela Fernández: None declared, Edilia García-Fernández: None declared, R. López-Sánchez: None declared, S. Castro: None declared, P. Morales-Garrido: None declared, Andrea García-Valle: None declared, Rosa Expósito: None declared, L. Exposito-Perez: None declared, Lorena Pérez Albaladejo: None declared, Ángel García-Aparicio: None declared, Miguel A González-Gay Grant/research support from: Pfizer, Abbvie, MSD, Speakers bureau: Pfizer, Abbvie, MSD, Ricardo Blanco Grant/research support from: AbbVie, MSD, and Roche, Speakers bureau: AbbVie, Pfizer, Roche, Bristol-Myers, Janssen, and MSD DOI: 10.1136/annrheumdis-2020-eular.1748

\section{OP0213 THE IMPACT OF TNFA INHIBITORS ON GLUCOCORTICOIDS USE AMONG PATIENTS WITH ARTHRITIS}

R. Hafthorsdottir ${ }^{1}$, A. Gunnarsdottir ${ }^{2}$, T. Love ${ }^{3}$, G. Gröndal ${ }^{4}$,

B. Gudbjornsson ${ }^{5}$ on behalf of ICEBIO. ${ }^{1}$ The University of Iceland, School of Health Sciences, Reykjavik, Iceland: ${ }^{2}$ Landspitali University Hospital, Hospital Pharmacy, Reykjavik, Iceland; ${ }^{3}$ Landspitali University Hospital, Department of Research, Reykjavik, Iceland; ${ }^{4}$ Landspitali University Hospital, Department of Rheumatology, Reykjavik, Iceland; ${ }^{5}$ Landspitali University Hospital, Centre for Rheumatology Research (ICEBIO), Reyjavik, Iceland

Background: Glucocorticoid steroid (GC) use among patients with arthritis is common. The introduction of TNFa inhibitors (TNFi) has been a breakthrough in the treatment of arthritis leading to remission for many patients. However, there is scarce information on the impact of TNFi on the use of GC among patients with inflammatory joint diseases.

Objectives: To explore oral GC use in patients with rheumatoid arthritis (RA), psoriatic arthritis ( $\mathrm{PsA})$, and axial spondyloarthritis (axSpA) before and after the initiation of TNFi therapy. Furthermore, to evaluate if patients on long term GC treatment were receiving active preventive osteoporosis treatment and how treatment with TNFi affected the use of topical steroids in patients with PsA.

Methods: Clinical data on patients with RA, PsA and axSpA who initiated TNFi therapy with etanercept, infliximab, adalimumab or golimumab for the first time between 2005-2015 was collected from the ICEBIO registry. ICEBIO is a nationwide registry on all patients treated with biologics for rheumatologic disorders in Iceland. The use of oral GC, topical steroids and bisphosphonates was collected from the Icelandic Prescription Medicines Registry (IPMR) for a period of four years, two years before and after the initiation of TNFi. Medication use was then evaluated by counting the number of individuals receiving a medication in a given year, the total number of prescriptions, and the defined daily dose (DDD). Five controls were randomly selected from IPMR and matched on age, sex and time frame. Results: 621 patients with RA, PsA or axSpA received 2630 prescriptions (4.2 prescription per patient; 3105 controls received 1337 prescriptions or 